CORPUS PUBLISHERS

Open Access

Journal of Dental

and Oral Surgery

(OAJDOS)

\section{Volume 3 Issue 1, 2022}

Article Information

Received date : January 19, 2022

Published date: January 28, 2022

*Corresponding author

Nara Hellen Campanha, Universidade

Estadual de Ponta Grossa (UEPG),

Ponta Grossa, Paraná, Brazil

\section{Keywords}

Stomatitis; Denture; Miconazole;

Adhesion; Antifungals Agents

Distributed under Creative Commons CC-BY 4.0

\section{Denture Adhesive Containing} Microparticles for Delivery of Miconazole:

\section{In Vivo Toxicity}

\author{
Paula Bisetto, Agnes Roberta Schwingel, Francine Baldin Able, Andrés Felipe \\ Cartagena Molina, Josiane Loch Ribeiro, Leandro Cavalcante Lipinski and Nara \\ Hellen Campanha ${ }^{*}$ \\ Universidade Estadual de Ponta Grossa (UEPG), Ponta Grossa, Paraná, Brasil
}

\section{Abstract}

The choice treatment for denture stomatitis are topical antifungals such as miconazole nitrate (MN). Targeting denture wearers, an experimental denture adhesive (EA) was developed containing polymeric microparticles (MPs) for the delivery of MN. Objectives: To investigate the systemic toxicity in rats of the EA added with MN MPs. Methods: Thirty-five Wistar rats received intraperitoneal injection of the materials: artificial saliva (AS) as solvent, Corega Cream $\mathbb{B}(\mathrm{CCDA})$, pure EA or EA added with MN MPs (sigla), and pure MN or MNMP. Animal behavior impairment (level 0-4) and weight (g) analyses were carried out at $0,24,48$ and $72 \mathrm{~h}$. Blood was collected to detect C-reactive protein. The intraperitoneal washing was analyzed through red blood cell and leukocyte counts and turbidity degree. Descriptive statistical analysis was performed for behavior and turbidity. Normality of red blood cells (thousand/L) and leukocytes (million/L) counts was verified (Shapiro-Wilk, $\mathrm{p}<0.0001$ ). Statistical analysis was performed using Kruskall-Wallis and Mann-Whitney U tests with Bonferroni adjustment. Results: No significant difference between weights of groups was found for time ( $\mathrm{p}=0,551$ ). No behavior alterations level 2, 3 or 4 were observed. The C-Reactive protein was negative for all groups. The leukocyte and red blood cell counts showed significant difference between the groups AS and EA+MNMP ( $\mathrm{p}=0.016$ and $\mathrm{p}=0.009$ respectively). No significant difference was found between $\mathrm{EA}+\mathrm{MNM}$ and the $\mathrm{CCA}(\mathrm{p}=0.917)$ group in the leukocyte count. Significance: The denture adhesive with antifungal presented similar results to those of the commercially available adhesive, and pure saliva was sufficient to cause peritoneum systemic toxicity.

\section{Clinical Implications}

Incorporation of miconazole in polymeric microparticles added to denture adhesives seems to be a safe formulation because it behaved similarly to the commercially available adhesive, presenting mild toxicity.

\section{Introduction}

Oral rehabilitation using complete dentures aims at restoring the occlusal support and the chewing function [1], as well as reinstating patients' self-confident after dental loss [2]. Quality clinical practice and the prosthesis routine maintenance must promote better adaptation, comfort, chewing ability and safety regarding the use of dentures, and denture adhesives might enhance this process [3-7]. Studies have been showing their effectiveness in reducing the displacement of mandibular and maxillary complete dentures with deficient retention and stability during chewing, swallowing and speech [8], improving their users' general satisfaction [7-15]. Over $65 \%$ of complete denture wearers present denture stomatitis [16] and, in most cases, it is caused by Candida albicans [17]. The treatment of this infection involves oral and prosthetic hygiene [18] and removal during the night [19], correction of the denture flaws [20] and topic and systemic use of antifungal agents. Miconazole nitrate (MN) is a broad spectrum triazole antifungal of first choice that has been employed in the treatment of candidiasis since 1970 [21-23]. It is catalogued in the Biopharmaceutical Classification System (SCF) as class II presenting low solubility in water and high permeability. This antifungal inhibits the cytochrome P450 14a-demethylase enzyme, inhibiting the synthesis of ergosterol, which is an essential component of the fungal cell membrane [24].

Microbiologically, it has demonstrated in vitro activity against several species of Candida. However, resistance of up to $17 \%$ has been reported to C. albicans e and 45\% regarding nonalbicans species [25]. Currently, it is the antifungal indicated in the EP treatment for topic use in its $2 \%$ gel formulation [19,26]. However, a weak response to topical antifungal is usual [19] due to their dilution and fast elimination through the salivary flow [27] in addition of the need for multiple applications, which might reduce the patients' cooperation [28]. With the purpose of optimizing the effects of topical medication, the technology associated to the changes in medicine release has been through remarkable evolution in the last few decades, as an attempt to increase their inherent advantages [29]. Regarding users of removable dental prosthesis, aiming at taking advantage of the extended period of permanence of such devices in their oral cavity, a denture adhesive containing polymeric microparticles that release MN was developed and was shown effective against in vitro C. albicans [30], based on the improvement of the antifungal solubility. The material presented adhesive properties similar to those of a commercially available adhesive and was non-toxic to invertebrated Organisms [30]. Considering the American Dental Association-ADA, specification [32], instruction regarding essential properties of an adhesive for complete dentures [31], such as the absence of toxicity, biocompatibility with the mucosa and ability to inhibit the growth of microorganisms adjacent to dentures, it seemed relevant to carry out an in vivo test of the adhesive developed [30,31]. The objective of this study was to confirm the results obtained in the in vitro evaluations, through a study on animals - rats - evaluating the toxicity of the new product. The null hypothesis (HO) of this study was that injection of experimental denture adhesive in the peritoneal cavity of rats would not promote behavioural and physiological alterations different form the artificial saliva nor the commercially available denture adhesive.

Material and Methods

Ethical Issues and Animal Management 
This study was approved by the Animal Use Ethics Committee - CEUA of the State University of Ponta Grossa, Paraná, Brazil (protocol n ${ }^{\circ}$ 6897/2016). For every study, the concept of homeostasis for the animals' wellbeing was established $[33,34]$. The technical norms International Organization for Standartization (ISO 10993-1157), 2015 [35] were considered, and the study aimed at observing the potential of systemic toxicity of extracts originated from the experimental adhesives and the control after intraperitoneal inoculation in rats. The animals were kept in cages with availability of ration and water ad libitum. On the days scheduled for inoculation and sacrifice, the animals were removed from the State University of Ponta Grossa, Paraná, Brazil vivarium and taken to the operation technique and experimental surgery laboratory of the same institution with prevention of noise and sharp movements.

\section{Sample}

The initial sample contained 35 Wistar rats (Rattus norvegicus), from 2 to 3 month old and weighing between $250 \mathrm{~g}$ and $390 \mathrm{~g}$, obtained from the State University of Pont Grossa, Paraná, Brazil vivarium. The calculation of the sample size was carried out using the software G Power [36] resulting in 5 animals in each experimental group.

\section{Materials Tested}

All the materials selected for the study were diluted in artificial saliva $(0,62 \mathrm{~g} / \mathrm{l}$ potassium chloride, 0,17 g/l calcium chloride, 0,06 g/l magnesium chloride, 4,82 g/l monobasic sodium hydrogen phosphate, $4,04 \mathrm{~g} / \mathrm{l}$ sodium phosphate dibasic heptahydrate and $0,0044 \mathrm{~g} / \mathrm{l}$ sodium fluoride in $1 \mathrm{l}$ distilled water) (Reinke et $\mathrm{al}, 2015$ ). So, the firs experimental group was named Artificial Saliva (AS). Other materials were solubilized in this solution to form all the other experimental groups: Corega Creme ${ }^{\circledR}$ (GSK, Buenos Aires, Argentina), as a reference of commercially available denture adhesive, composed by partial mixed sodium/calcium salt of polycarboxycellulose, mineral oil and vaseline, conformed group Corega Creme Adhesive (CCA); An experimental adhesive previously developed (Cartagena et al, 2017), composed by Gantrez MS-955 (R), sodium carboxymethyl cellulose, liquid parafin, white petrolatum, Versagel ${ }^{\circledR}$, BHT, colloida silica and Nipazol ${ }^{\circledR}$ (propylparaben) formed group Experimental Denture Adhesive (EA); miconazole nitrate encapsulated in a mixture of Eudragit L-100 and Gantrez MS-955 (R) microparticles, composed by water, miconazole nitrate (2\%), Eudagrit L-100, Gantrez MS-955 (R) and ethanol (Cartagena et al, 2017) formed group Miconazole Nitrateloaded Microparticles (MNM); the two last groups joined formed group Experimental Denture Adhesive with Miconazole Nitrateloaded Microparticles (EA+MNM), being the miconazole nitrate at $2 \%$ in the mixture; pure miconazole nitrate (Sigma Aldrich, Sain Louis, Missouri, EUA) formed group MN. Finally, group C was conformed without any material, as follows.

The materials belonging to all groups were solubilized in artificial saliva, as an extraction means and, following the ISO 10993-1 standard35, for each $20 \mathrm{ml}$ extraction means, 2 to $4 \mathrm{~g}$ material was used. The artificial saliva was aseptically filtered inside the laminar flow hood and added to each material. The flasks containing the extraction mean with and without material were kept at $37^{\circ} \mathrm{C}$ for $72 \mathrm{~h}$ and then transferred to sterile flasks and then stored until use. The animals belonging to group $\mathrm{C}$ did not receive any type of material, but were submitted to the same management, transportation and anaesthesia procedures as the ones in the other groups. The MN group was included in the study to differentiate the intrinsic toxicity of this drug from that obtained by the groups containing it and the CCA group was inserted as the parameter of toxicity of a commercially available material. Likewise, the AS group was included to verify the toxicity of the dissolution means of all materials under study.

\section{Procedures for the intraperitoneal injection of the materials tested}

Trichotomy was carried out followed by intraperitoneal inoculation $[37,38]$ of the extracts in the proportion of $50 \mathrm{ml} / \mathrm{Kg}$ animal body weight. The animal was held from the back and positioned with the ventral surface upwards. The injection was applied in the abdomen posterior quadrant, on the right side of the animal and on the left side of the operator. The substance was injected in the peritoneal cavity between the abdomina organs. The animals were numbered 1 to 5 through marks on their tails, according to the groups of materials to be tested. Immediately after injection and identification, the animals were transferred to the transportation cages and remained in the surgical center until the last animal was submitted to the experimental procedures, and after that returned to the vivarium resuming their daily routine.

\section{Weight and behavioural analysis of the animals}

The animals were weighed using digital scales and analyzed in relation to their behaviour at the moments $0 \mathrm{~h}$ (baseline-immediately before the injection of samples) 24 $\mathrm{h}, 48 \mathrm{~h}$ and $72 \mathrm{~h}$ after the injection. The animals' weight and individual behaviour were recorded in a specific card to allow the descriptive analysis of the groups, evaluated by the Systemic Toxicity Index - STI - ISO 10993 part 11.35 According to this system, animal without symptoms is classified as normal and given serum level 0; when animal shows mild adverse symptoms, but noticeable, of hypokinesia, dyspnea or abdominal irritation, it is considered light response to injection and recorded serum level 1; an animal shows definite evidence of hypokinesia, dyspnea, abdominal irritation, ptosis or diarrhea (usually the body weight drops sharply) is considered moderate response to injection and recorded serum level 2; severe response is considered when the animal shows prostration, cyanosis, shaking or severe symptoms of dyspnea, abdominal irritation, ptosis or diarrhea (extreme loss of body weight) and the score recorded is 3 . The worst scenario is the death of animal, recorded score 4

Analysis of the peritoneal wash for the investigation of $\mathrm{C}$-reactive protein and verification of turbidity and cell count

Blood collection for the C-Reactive protein analysis was carried out through cardiac puncture. With that purpose, after the behavioural observation period at $0 \mathrm{~h}, 24 \mathrm{~h}$, $48 \mathrm{~h}$ and $72 \mathrm{~h}$ and the last weighing, the animals were sedated and anesthetised with intramuscular ketamin and xylazin $(50 \mathrm{mg} / \mathrm{Kg})$. An incision in the medium line, aiming at the peritoneal region was carried out [40,41]. The blood collected was mixed with $3,2 \%$ sodium citrate, centrifuged and the supernatant poured in tubes for later analysis. For the turbidity analysis and cell count, the animals' abdomen peritoneal cavity was washed with $5 \mathrm{ml}$ saline solution, sucked, and treated with the EDTA contained in the test tubes. The samples of both blood and wash were identified and sent to a clinical analysis laboratory (Laboratório Oscar Pereira, Ponta Grossa-PR, Brazil) for the evaluation of the presence of C-Reactive protein (registered as positive or negative), leukocyte (million/L) and red blood cell (thousand/L) count, as well as the turbidity analysis of the cell resuspension (qualitative). All evaluations were carried out by an experienced analyst and a technical report was issued $[42,43]$. The leukocyte and red blood cell count was carried out using the equipment bc- 2800 vet. The turbidity degree analysis was performed visually following a $1-5$ scale [44].

\section{Data Analysis}

For the behavioural descriptive statistics, the animals' symptoms were observed and classified [33], throughout the times $0 \mathrm{~h}, 24 \mathrm{~h}, 48 \mathrm{~h}$ and $72 \mathrm{~h}$, according to the systemic toxicity serum levels and the frequency percentages were calculated. The frequency of crosses was established for the turbidity descriptive statistics, which was considered qualitative to obtain the frequencies among the groups. It was considered non-parametric to proceed the remaining analyses, since it is an ordinal qualitative variable. The normality of leukocyte (million/L) and red blood cell (thousand/L) count was tested using the Shapiro-Wilk test and neither of them followed a normal distribution $(\mathrm{p}<0,0001)$. Therefore, the Kruskall-Wallis test was employed to verify the differences between groups and Mann-Withney $U$ test with Bonferroni correction was used as post-hoc to verify differences between groups in pairwise comparisons. All tests were considered significant when $\mathrm{p}<0.05$ and the analyses were aided by the software SPSS 20.0 [39].

\section{Results}

\section{Animals' Weight and Behavioural Analysis}

The Shapiro-Wilk test demonstrated that the animals' weight values did not show a normal distribution $(\mathrm{p}=0.009)$. The median and the interquartile interval in each group tested are shown in Table 1. No significant difference was observed between groups or when their weight was compared within each observation time: $0 \mathrm{~h}(\mathrm{p}=0.672), 24$ $\mathrm{h}(\mathrm{p}=0.865), 48 \mathrm{~h}(\mathrm{p}=0.551)$ and $72 \mathrm{~h}(\mathrm{p}=0.228)$. The percentages $(\%)$ of frequency of alteration of the animals' behaviour, according to the systemic toxicity serum level $(0,1$, $2,3$ or 4$)$, within the times, for the groups $(n=5)$ under study demonstrated absent serum alterations levels 2, 3 or 4 in any of the experimental groups or the times evaluated. The group EA + MNM showed level 1 of behavioural serum alteration in the $24 \mathrm{~h}, 48 \mathrm{~h}$ and 72 h observations in one animal only (20\%). Identical behaviour was seen in the group CCA. Among the animals in group $\mathrm{MN}$ ( $\mathrm{n}=6$ only for this group), one presented behavioural serum alteration of level 1 at $48 \mathrm{~h}$ and kept that behaviour up to $72 \mathrm{~h}$. 
Table 1: Descriptive statistics of the animals' weight (g) within each time observed according to the groups.

\begin{tabular}{|c|c|c|c|c|c|c|c|c|}
\hline \multirow{2}{*}{ Group } & \multicolumn{2}{|c|}{$\mathbf{0 h}$} & \multicolumn{2}{c|}{$24 \mathbf{h}$} & \multicolumn{2}{c|}{48 h } & \multicolumn{2}{c|}{72 h } \\
\cline { 2 - 9 } & Median & IQI & Median & IQI & Median & IQI & Median & IQI \\
\hline GENERAL & 328.00 & 34.00 & 324.00 & 26.00 & 318.00 & 30.00 & 318.00 & 20.00 \\
\hline C & 316.00 & 45.00 & 320.00 & 47.00 & 320.00 & 54.00 & 326.00 & 38.00 \\
\hline AS & 354.00 & 73.00 & 360.00 & 74.00 & 338.00 & 70.00 & 360.00 & 76.00 \\
\hline CCA & 334.00 & 37.00 & 320.00 & 40.00 & 310.00 & 37.00 & 310.00 & 34.00 \\
\hline EA & 328.00 & 34.00 & 318.00 & 38.00 & 314.00 & 43.00 & 312.00 & 41.00 \\
\hline EA+MN M & 336.00 & 32.00 & 332.00 & 29.00 & 312.00 & 30.00 & 310.00 & 27.00 \\
\hline MNM & 326.00 & 20.00 & 320.00 & 15.00 & 320.80 & 14.00 & 322.00 & 14.00 \\
\hline MN & 328.00 & 31.00 & 326.00 & 18.00 & 326.40 & 17.00 & 318.00 & 18.00 \\
\hline
\end{tabular}

Results of C-Reactive Protein and Verification of Turbidity and Cell Count

The C-Reactive protein investigation did not show positive results for any of the experimental groups. The turbidity frequencies found for each experimental group are shown in Table 2 .

Table 2: Frequencies of turbidity crosses in each group.

\begin{tabular}{|c|c|c|c|c|c|c|c|c|c|c|c|c|c|}
\hline \multirow{2}{*}{ Total } & \multicolumn{2}{|c|}{$\mathbf{0}$} & \multicolumn{2}{|c|}{+} & \multicolumn{2}{|c|}{++} & \multicolumn{2}{|c|}{+++} & \multicolumn{2}{|c|}{+++} & \multicolumn{2}{|c|}{+ Total } \\
\cline { 2 - 13 } & $\mathbf{N}$ & $\%$ & $\mathbf{N}$ & $\%$ & $\mathbf{N}$ & $\%$ & $\mathbf{N}$ & $\%$ & $\mathbf{N}$ & $\%$ & $\mathbf{N}$ & $\%$ & \\
\hline C & 3 & $60.0 \%$ & 2 & $40.0 \%$ & 0 & $0.0 \%$ & 0 & $0.0 \%$ & 0 & $0.0 \%$ & 0 & $0.0 \%$ & 5 \\
\hline AS & 0 & $0.0 \%$ & 2 & $40.0 \%$ & 3 & $60.0 \%$ & 0 & $0.0 \%$ & 0 & $0.0 \%$ & 0 & $0.0 \%$ & 5 \\
\hline CCA & 0 & $0.0 \%$ & 0 & $0.0 \%$ & 3 & $60.0 \%$ & 1 & $20.0 \%$ & 0 & $0.0 \%$ & 1 & $20.0 \%$ & 5 \\
\hline EA & 0 & $0.0 \%$ & 1 & $20.0 \%$ & 3 & $60.0 \%$ & 1 & $20.0 \%$ & 0 & $0.0 \%$ & 0 & $0.0 \%$ & 5 \\
\hline $\begin{array}{c}\text { EA + } \\
\text { MNM }\end{array}$ & 0 & $0.0 \%$ & 0 & $0.0 \%$ & 0 & $0.0 \%$ & 1 & $20.0 \%$ & 0 & $0.0 \%$ & 4 & $80.0 \%$ & 5 \\
\hline MNM & 0 & $0.0 \%$ & 2 & $40.0 \%$ & 2 & $40.0 \%$ & 1 & $20.0 \%$ & 0 & $0.0 \%$ & 0 & $0.0 \%$ & 5 \\
\hline MN & 0 & $0.0 \%$ & 0 & $0.0 \%$ & 2 & $33.3 \%$ & 2 & $33.3 \%$ & 0 & $0.0 \%$ & 2 & $33.3 \%$ & 6 \\
\hline Total & 3 & & 7 & & 13 & & 6 & & 0 & & 7 & & 36 \\
\hline
\end{tabular}

The turbidity analysis showed that group C presented degrees 0 and 1. Group AS presented degrees 1 and 2 of turbidity. Groups EA and MNM showed degrees 1,2 and 3. Group CCA showed degrees 2 and 4. Groups EA+MNM and MN showed degree 5. The Kruskall-Wallys test for turbidity showed statistical difference between the groups ( $\mathrm{p}=0.004$, Table 4). Regarding the turbidity analysis, the pairwise comparison showed statistical difference between groups AS and EA+MNM ( $\mathrm{p}=0.006)$ and $\mathrm{MN}(\mathrm{p}=0.021)$. Group CCA differed from groups $C(p=0.042)$ and $E A+M N M \quad(p=0.041)$. Group $\mathrm{EA}+\mathrm{MNM}$ also presented statistical difference in relation to the groups $\mathrm{MN}(\mathrm{p}=0.013), \mathrm{C}$ $(\mathrm{p}=0.031)$ and $\mathrm{MNM}(\mathrm{p}=0,009)$. Groups $\mathrm{C}$ and $\mathrm{MN}$ were also different one from another $(\mathrm{p}=0.009)$. The median and interquartile interval in each group tested are shown in Table 3. The Kruskall-Wallys test for leukocytes $(\mathrm{p}=0.001)$ and red blood cells $(\mathrm{p}=0.004)$ revealed statistical difference between the groups. The pairwise comparison of groups using the Mann-Withney test is shown in Table 4. In the leukocyte investigation, all experimental groups showed counts statistically higher than the control group (C). Regarding the same parameter, the experimental adhesive with $(\mathrm{EA}+\mathrm{MNM})$ or without (EA) miconazole microparticles and the pure miconazole nitrate $(\mathrm{MN})$ presented statistically similar cell counts to that of the commercially available cream adhesive (CCA). In the red blood cell count, groups AS, EA and EA+MNM presented statistically higher cell counts than that of the control group. These values are shown in the graph of Figure $1 \& 2$.

Table 3: Descriptive statistics of leukocyte and red blood cell count in each group.

\begin{tabular}{|c|c|c|c|c|c|}
\hline \multirow{2}{*}{$($ million/L) } & \multicolumn{2}{|c|}{ Leukocytes } & \multirow{2}{*}{ (thousand/L) } & \multicolumn{2}{c|}{ Red blood cell } \\
\cline { 2 - 3 } & $\mathrm{MD}^{*}$ & $\mathrm{IQR}$ & & $\mathrm{MD}^{*}$ & $\mathrm{IQR}$ \\
\hline AS & 9500 & 7750 & $\mathrm{AS}$ & 30 & 24 \\
\hline
\end{tabular}

\begin{tabular}{|c|c|c|c|c|c|}
\hline CCA & 23800 & 17850 & CCA & 0 & 190 \\
\hline EA & 19000 & 14500 & EA & 10 & 30 \\
\hline EA+MNM & 23900 & 8150 & EA+MNM & 1510 & 2020 \\
\hline C & 3300 & 1400 & C & 0 & 0 \\
\hline MNM & 6000 & 5350 & MNM & 20 & 50 \\
\hline MN & 9100 & 35300 & MN & 575 & 1150 \\
\hline
\end{tabular}

Source: AS = Artificial Saliva; CCA $=$ Corega Cream Adhesive $\left.{ }^{(}\right)$EA $=$Experimenta Adhesive; $\mathrm{MNM}=$ Miconazole Nitrate Microparticles; $\mathrm{C}=$ Control $; \mathrm{MN}=$ Miconazole Nitrate. $\mathrm{MD}=$ median; $\mathrm{IQR}=$ interquartile range.

Table 4: Statistical test results of leukocyte and red blood cell pairwise comparison.

\begin{tabular}{|c|c|c|c|}
\hline \multirow{2}{*}{ Groups } & LEUKOCYTES & RED BLOOD CELLS & TURBIDITY \\
\hline & p-value & p-value & p-value \\
\hline AS X CCA & $0.016^{\star}$ & 0.829 & 0.059 \\
\hline AS X EA & 0.175 & 0.523 & 0.107 \\
\hline AS X EA+MNM & $0.016^{*}$ & $0.009^{*}$ & $0.006^{*}$ \\
\hline AS X C & $0.009^{*}$ & $0.018^{*}$ & 0.18 \\
\hline AS X MNM & 0.53 & 0.667 & 0.729 \\
\hline AS X MN & 0.855 & 0.054 & $0.021^{\star}$ \\
\hline CCA X EA & 0.251 & 0.592 & 0.558 \\
\hline CCA X EA+MNM & 0.917 & $0.026^{*}$ & $0.041^{*}$ \\
\hline CCAXC & $0.009^{*}$ & 0.136 & $0.042^{*}$ \\
\hline CCA X MNM & $0.009^{*}$ & 0.911 & 0.178 \\
\hline CCA XMN & 0.144 & 0.112 & 0.434 \\
\hline $\mathrm{EA}+\mathrm{MNM} \mathrm{X} \mathrm{MN}$ & 0.117 & $0.015^{*}$ & $0.013^{*}$ \\
\hline EAXC & $0.009^{*}$ & $0.005^{*}$ & 0.046 \\
\hline EA X MNM & 0.175 & 1 & 0.343 \\
\hline EA X MN & 0.465 & 0.065 & 0.165 \\
\hline $\mathrm{EA}+\mathrm{MNM} \mathrm{X} \mathrm{C}$ & $0.009^{*}$ & $0.005^{*}$ & $0.031^{*}$ \\
\hline $\mathrm{EA}+\mathrm{MNM} \mathrm{X}$ MNM & $0.009^{*}$ & $0.016^{*}$ & $0.009^{*}$ \\
\hline $\mathrm{EA}+\mathrm{MNM} \mathrm{X} \mathrm{MN}$ & 0.1 & 0.465 & 0.106 \\
\hline CX MNM & $0.009^{*}$ & 0.054 & 0.195 \\
\hline C X MN & $0.006^{\star}$ & $0.013^{*}$ & $0.040^{*}$ \\
\hline MNM X MN & 0.234 & 0.052 & 0.058 \\
\hline
\end{tabular}

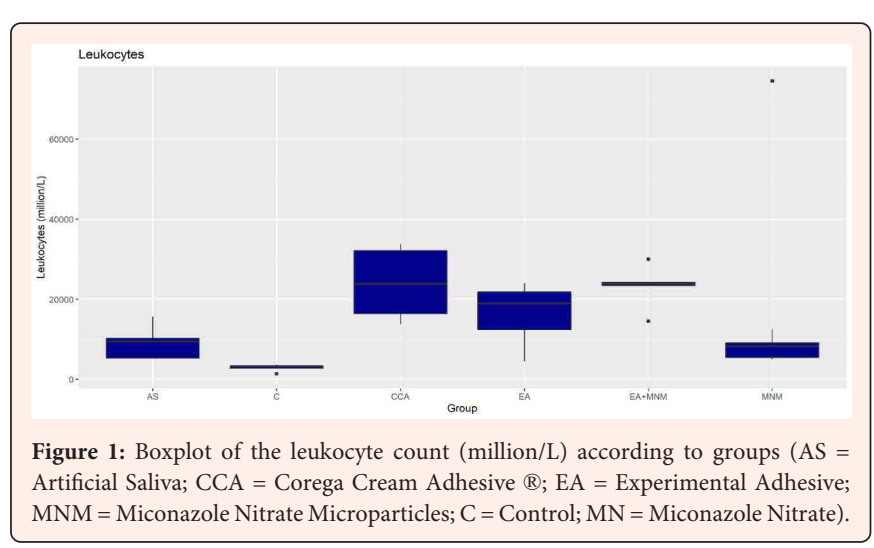




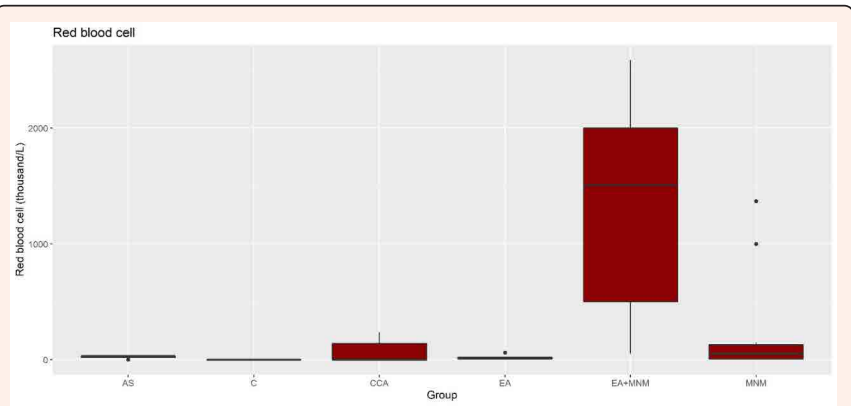

Figure 2: Boxplot of the red blood cell count (thousand/L) according to groups (AS $=$ Artificial Saliva CCA $=$ Corega Cream Adhesive ${ }^{\circledR}$; $\mathrm{EA}=$ Experimental Adhesive $\mathrm{MNM}=$ Miconazole Nitrate Microparticles; $\mathrm{C}=$ Control; $\mathrm{MN}=$ Miconazole Nitrate).

Regarding both leukocytes and red blood cells, there was significant difference between the pure saliva group (AS) when compared to the experimental adhesive with microparticles ( $\mathrm{p}=0.016$ and $\mathrm{p}=0.009$ ). No significant difference was found between the adhesive with microparticles and the commercially available adhesive $(p=0.917)$ in the leukocyte count. When red blood cells were counted, significant difference $(\mathrm{p}=0.026)$ was observed. Between the control group and pure saliva group, significant difference was found for leukocytes $(\mathrm{p}=0.009)$ and red blood cells $(\mathrm{p}=0.018)$. The leukocyte coun showed significant difference when compared to the groups AS and CCA ( $p=0.016)$, and also between CCA and MNM ( $p=0.009$ ). As for the red blood cells, the group EA+MNM presented significant difference when compared to the groups CCA $(\mathrm{p}=0.026)$ and MNM $(\mathrm{p}=0.016)$. No significant difference was observed between groups EA+MNM and MN $(\mathrm{p}=0.465)$. The turbidity analysis was compared to the leukocyte and red blood cell values to verify whether there was any correlation between them. Significant correlation was observed between: turbidity $\mathrm{x}$ leukocytes $(\mathrm{p}=<0.001)$ and turbidity $\mathrm{x}$ red blood cells $(\mathrm{p}=0.004)$. Frequency turbidity values were then pairwise compared in relation to leukocytes and red blood cells (Table 5). The number of leukocytes present in the samples with turbidity 5 was statistically different from turbidity $0(\mathrm{p}=0.004)$ and also from turbidity $1(\mathrm{p}=0.041)$. These values are shown in the graph of Figure 3A. Regarding red blood cells, in addition to the differences found between turbidity 0 and $5(\mathrm{p}=0.002)$ and 1 and $5(\mathrm{p}<0.001)$, there was also difference between frequencies 2 and $5(\mathrm{p}=0.002)$. These values are presented in the graph of Figure 3B.

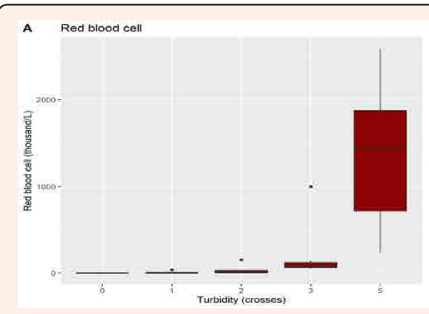

Figure 3A: Bloxplot of leukocyte count (million/L) according to turbidity frequency (AS = Artificial Saliva; CCA = Corega Cream Adhesive ${ }^{\mathbb{R}}$; EA $=$ Experimental Adhesive; $\mathrm{MNM}=$ Miconazole Nitrate Microparticles; C = Control; $\mathrm{MN}=$ Miconazole Nitrate).

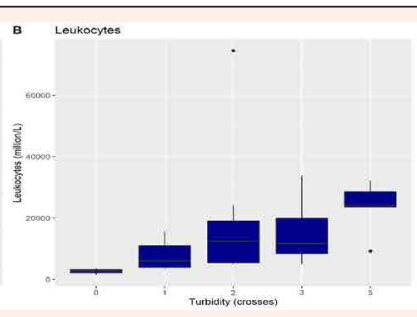

Figure 3B: Bloxplot of red blood cell count (thousand/L) according to turbidity frequency $(\mathrm{AS}=$ Artificial Saliva; CCA $=$ Corega Cream Adhesive (R); EA = Experimental Adhesive; MNM $=$ Miconazole Nitrate Microparticles; $\mathrm{C}$ $=$ Control; $\mathrm{MN}=$ Miconazole Nitrate).

Table 5: Turbidity degree in relation to the leukocyte and red blood cell values.

\begin{tabular}{|c|c|c|}
\hline \multirow{2}{*}{ Turbidity } & LEUKOCYTES & RED BLOOD CELLS \\
\cline { 2 - 3 } & $\mathrm{p}$-value & $\mathrm{p}$-value \\
\hline $0 \times 1$ & 0.192 & 0.645 \\
\hline $0 \times 2$ & 0.118 & 0.207 \\
\hline $0 \times 3$ & 0.206 & 0.076 \\
\hline $0 \times 5$ & $0.004^{*}$ & $0.002^{*}$ \\
\hline $1 \times 2$ & 0.128 & 0.296 \\
\hline
\end{tabular}


cells might indicate increase in the bone marrow activity, due to an intoxication proces [48]. Group C did not present red blood cell count values, similarly to commercially available cream adhesive group (CCA), which demonstrates that the surgical procedure did not influence the counting of these cells. The red blood cell count showed that the experimental adhesive with miconazole microparticles did not behave in the same way as the commercially available adhesive or the control group, since the number of red blood cells found was higher, thus indicating the onset of an inflammatory process. Curiously, the pure experimental adhesive did not influence the number of red blood cells found in the intraperitoneal cavity of the animals. This material contains substances such as vaseline and silica, which are commonly used materials in compositions of skin moisturizers [49], ointments, emollient products to treat skin diseases, ear diseases [50], and treatment of heart illnesses [51], which have been largely and safely used by human beings. The buthyhydroxytoluene used is also a conservative and antioxidant used both in cosmetic and food industries [52]. These might be reasons why the experimental adhesive was found to be so biocompatible.

The relation between the turbidity degree and the number of cells was investigated in this study and was positive in some cases, since the turbidity scores seem to be related to the presence of cells in the intraperitoneal wash, both leukocytes and red blood cells. However, turbidity might be also related to the presence of cell fragments, fibrin deposition, and peritoneum calcification [53], as well as segmented neutrophils, macrophages, lymphocytes, and eosinophils [54]. For this reason, it was not always related to the presence of leukocytes or red blood cells in our experiments. The result obtained suggest non-toxicity or tolerable toxicity of the material being developed, since its behaviour was similar to that already commercially available. Regarding the turbidity degree observed, higher values might be related to the presence of miconazole nitrate in the composition of the solutions used, since degree 5 turbidity values were found more frequently in groups $\mathrm{E}+\mathrm{MNM}$ and $\mathrm{MN}$. Group $\mathrm{MN}$ did not present toxicity in some studies developed. However, the systemic use of NM has been reported to trigge hepatic and cardiovascular side effects [27,31]. To Coley et al., 1997 cardiovascular side effects such as cardiac arrhythmia might occur due to fast intravenous administration, insufficient dilution and the drug vehicle. The results found suggest that the toxicity of the experimental material proposed in this study was shown to be absent in some case and in others comparable to that in the control, which suggests biological safety in its use. However, other tests, such as the subcutaneous implant and histopathological analysis should be carried out to confirm the toxicity of the material investigated. This would result in data to enable the performance of tertiary clinical tests.

\section{Conclusion}

Although the experimental adhesive with the addition of antifungal agent presented mild toxicity, it was not possible to verify toxicity higher than that of the commercially available materials or that of the artificial saliva, since the use of pure saliva per se was sufficient to cause peritoneum alteration. The adhesive with addition of miconazole microparticles behaved similarly to the commercially available product in most of the cases analysed.

Acknowledgments: The authors thank the AAC \& T Assessoria em Pesquisa Científica for conducting the statistical analysis in this work.

\section{References}

1. Mazurat NM, Mazurat RD (2003) Discuss before fabricating: communicating the realities of partial denture therapy. Part II: Clinical outcomes. J Can Dent Assoc 69(2): 96-100

2. Friedman N, Landesman HM, Wexler M (1987) The influences of fear, anxiety, and depression on the patient's adaptive responses to complete dentures. Part I. J Prosthet Dent 58(6): 687-689.

3. Slaughter A, Katz RV, Grasso JE (1999) Professional attitudes toward denture adhesives: a Delphi technique survey of academic prosthodontists. J Prosthet Dent 82(1): 80-89.

4. Adisman IK (1982) The use of denture adhesives as an aid to denture treatment. J Prosthet Dent 62(6): 711-715

5. Ghani F, Picton DCA (1994) Some clinical investigations on retention forces of maxillary complete dentures with the use of denture fixatives. J Oral Rehabil 21(6) $631-640$

6. Coates AJ (1995) Denture adhesives: a review. Aust Prosthodont J 9: 27-31.

7. Grasso JE, Rendell J, Gay T (1994) Effect of denture adhesive on the retention and stability of maxillary dentures. J Prosthet Dent 72(4): 399-405

8. Ghani F, Picton DC, Likeman PR (1991) Some factors affecting retention forces with the use of dentures fixatives on vivo. Br Dent J 171(1): 15-21.

9. Psillakis JJ, Wright RF, Grbic JT, Lamster IB (2004) In practice evaluation of a denture adhesive using a gnathometer. J Prosthodont 13(4): 244-250.

10. Tarbet WJ, Boone M, Schmidt NF (1980) Effect of a denture adhesive on complete denture dislodgement during mastication. J Prosthet Dent 44(4): 374-378.

11. Spenciere MCRL, Zavanelli AC, Carvalho Júnior H, Zavanelli RA (2009) Impact of the use of adhesive strip over the satisfaction degree of institutionalized patients and wearers of conventional complete denture. Rev Odontol, UNESP 38(6): 335340 .

12. Munoz CA, Gendreau L, Shanga G, Magnuszewski T, Fernandez P, et al. (2012) A clinical study to evaluate denture adhesive use in well-fitting dentures. Prosthodont 21(2): 123-129.

13. Berg E (1984) The influence of some anamnestic, demographic and clinical variables on patient acceptance of new complete dentures. Acta Odontol Scand 42(2): 119.

14. Pradies G, Sanz I, Evans O, Martnez F, Sanz M (2009) Clinical study comparing the efficacy of two denture adhesives in complete denture patients. Int J Prosthodont 22(4): 361-367.

15. Zavanelli RA, Magalhães JB, Guilherme AS, Melo LGN, Cardoso LC, et al. (2010) Impact of the use of adhesive strip over the quality of life of institutionalized patients and wearers of conventional complete denture. Rev Odontol UNESP 39: 291-297.

16. Rabiei M, Kasemnezhad E, Masoudi rad H, Shakiba M, Pourkay H (2010) Prevalence of oral and dental disorders in institutionalized elderly people in Rasht, Iran. Gerontology 27(3): 174-177.

17. Coco BJ, Bagg J, Cross LJ, Jose A, Cross J, et al. (2008) Mixed Candida albican and Candida glabrata populations associated with the pathogenesis of denture stomatitis. Oral Microbiol Immunol 23(5): 377-383.

18. Pires FR, Santos EBD, Bonan PRF, de Almeida OP, Lopes MA (2002) Denture stomatitis and salivary Candida in Brazilian edentulous patients. J Oral Rehabil 29(11): 1115-1159.

19. Neppelenbroek KH, Pavarina AC, Palomari DM, Sgavioli EM, Spolidorio LC, et al. (2008) Effectiveness of microwave desinfection of complete dentures on the treatment of Candida-related denture stomatitis. J Oral Rehabil 35(11): 836-846.

20. Amanlou M, Beitollahi JM, Abollahzadeh S, Tohidast EZ (2006) Miconazole gel compared with Zataria Multiflora Boiss. Gel in the treatment of oral stomatitis. Phytother Res 20(11): 966-969.

21. Sawyer PR, Brogden RN, Pinder RM, Speight TM, Avery GS (1975) Miconazole: a review of its antifungal activity and therapeutic efficacy. Drugs 9(6): 406-423.

22. Bouckaert S, Schautteet H, Lefebvre RA, Remon JP, van Clooster R (1992) Comparison of salivary miconazole concentrations after administration of a bioadhesive slow-release buccal tablet and an oral gel. Eur J Clin Pharmacol 43(2): 137-140.

23. Mandal TK (2000) Swelling-controlled release system for the vaginal delivery of miconazole. Eur J Pharm Biopharm 50(3): 337-343.

24. Yoshida Y (1988) Cytochrome P450 of fungi: primary target for azole antifungal agents. Curr Top Med Myco 2: 388-418.

25. Manfredi M, McCullough MJ, Polonelli L, Conti S, Al Karaawi ZM, et al. (2006) In vitro antifungal susceptibility to six antifungal agents of 229 Candida isolates from patients with diabetes mellitus. Oral Microbiol Immunol 21(3): 177-182.

26. Barasch A, Griffin AV (2008) Miconazole revisited: new evidence of antifungal efficacy from laboratory and clinical trials. Future Microbiol 3(3): 265-269.

27. Banting DW, Hill AS (2001) Microwave desinfection of dentures for the treatment of oral candidiasis. Spec Care Dentist 21(1): 4-8.

28. Blomgren J, Berggren U, Jontell M (1998) Fluconazole versus nystatin in the treatment of oral candidosis. Acta Odontol Scand 56(4): 202-205.

29. Das NG, Das SK (2003) Controlled-release of oral dosage forms. Formulation, fill \& finish - a technology primer Pharm Tec 27: 10-16.

30. Cartagena AF, Esmerino LA, Polak Junior R, Olivieri PS, Domingos MM, et al. (2017) New denture adhesive containing miconazole nitrate polymeric microparticles: Antifungal, adhesive force and toxicity properties. Dent Mater 33: 53-61. 
31. Coley KC, Crain JL (1997) Miconazole-induced fatal dysrhytmia. Pharmacotherapy 17(2): 379382

32. American Dental Association (ADA) (2005) Standard $n^{\circ} 41$. Recommended standard practices for biological evaluation of dental materials.

33. Baumans V (2006) The laboratory mouse. In: Poole T, The UFAW handbook on the care and management of laboratory animals. British: Blackwell Science 1: 282-312.

34. Rivera EAB (2010) Welfare in animal testing. In: Feijó AGS, Braga LMGM, Pitrez PMC. Animals in research and teaching: ethical and technical aspects. EdiPUCRS, pp. 74-88.

35. Internacional Organization of Standardization (2015) ISO 10993-11. Tests for systemic toxicity: biological evaluation of medical devices. Switzerland.

36. Jaykaran Charan, Kantharia ND (2013) How to calculate sample size in animal studies? J Pharmacol Pharmacother 4(4): 303-306.

37. Goldman L, Bennett C (2000) Tratado de Medicina Interna. 21 $1^{\text {a }}$ Ed. Rio de Janeiro: Editora Guanabara Koogan v.1.

38. Lumar V, Abbas A, Fausto N (2005) Patologia: bases patológicas das doenças. $7^{\mathrm{a}} \mathrm{ed}$ São Paulo: Editora Elsevier Ltda.

39. IBM Corp (2011) IBM SPSS Statistics for Windows, Version 20.0. IBM Corp , Armonk, NY, USA.

40. Pereira KR, Neves E, Fortulan CA, Rollo JMD (2011) Biocompatibilidade in vivo do BR3G: vitrocerâmico com cristais de anortita. Revista Citino 1(1): 10.

41. Pal A, Badyal RK, Vasishta RK, Attri SV, Thapa BR, et al. (2013) Biochemical, histological, and memory impairment effects of chronic copper toxicity: a model for non-Wilsonian brain copper toxicosis in Wistar rat. Biol Trace Elem Res 153(1 3): $257-268$

42. Zayerzadeh E, Shabanian M, Koohi MK (2018) Toxicopathological examination after repeated intraperitoneal administration of silver nanoparticles in the Wistar rat model. Nanomed Res J 3: 51-57.

43. Pari L, Amudha K (2011) Hepatoprotective role of naringin on nickel-induced toxicity in male Wistar rats. Eur J Pharmacol 650(1): 364-370.
44. Smith P, Kuster N, Ebert S, Chevalier HJ (2007) GSM and DCS wireless communication signals: combined chronic toxicity/carcinogenicity study in the Wistar rat. Radiat Res 168(4): 480-492.

45. Araújo FI, Jácome DT, Rêgo AC, Azevedo IM, Egito ES, et al. (2010) Effect of the simvastatin in abdominal sepsis of diabetic rats. Rev Col Bras Cir 37(1): 39-44.

46. Yildirim S, Celikezen FC, Oto G, Sengul E, Bulduk M, et al. (2018) Investigation of protective effects of litium borate on blood and histopathological parameters in acute cadmiuminduced rats. Biol Trace Elem Res 182(2): 287-294.

47. Pai MH, Huang $\mathrm{KH}$, Wu CH, Yeh SL (2010) Effects of dietary arginine on inflammatory mediator and receptor of advanced glycation end products (RAGE) expression in rats with streptozotocininduced type 2 diabetes. Br J Nutr 104(5): 686-692.

48. San SE, Zimmerman T, Zubia A, Vara Y, Martin E, et al. (2013) Design, synthesis and functional evaluation of leukocyte function associated antigen-1 antagonists in early and late stages of cancer development. J Med Chem 56(3): 735-747.

49. Iyer S, Kievsky Y, Sokolov I (2007) Fluorescent silica colloids for study and visualization of skin care products. Skin Res Technol 13(3): 317-322.

50. Bauters T, Van Schandevyl G, Laureys G (2016) Safety in the use of vaseline during oxygen therapy: the pharmacist's perspective. Int J Clin Pharm 38(5): 1032-1034.

51. Galagudza M, Korolev D, Postnov V, Naumisheva E, Grigorova Y, et al. (2012) Passive targeting of ischemic-reperfused myocardium with adenosine-loaded silica nanoparticles. Int J Nanomedicine 7: 1671-1678.

52. Lee MR, Lin CY, Li ZG, Tsai TF (2006) Simultaneous analysis of antioxidants and preservatives in cosmetics by supercritical fluid extraction combined with liquid chromatography-mass spectrometry. J Chromatogr A 1120(1-2): 244-251.

53. Hamada C, Nakamoto H, Suzuki Y (2018) Morphologic characteristics of macroscopic peritoneal finding in patients with peritoneal dialysis. J Artif Organs 21(1): 102-109.

54. Lhamas Cl, Duarte Ca, Lubeck I, Silva Mng, Leite CT, et al. (2015) Influence of intestinal parasitism on peritoneal fluid and hematological parameters in horses used for traction. Arq Bras Med Vet Zootec 67(2): 381-390. 